\title{
Sources and Transport of Nitrogen in Arid Urban Watersheds
}

\author{
Rebecca L. Hale, ${ }^{* \dagger, \ddagger}$ Laura Turnbull, ${ }^{\S}, \|$ Stevan Earl, ${ }^{\S}$ Nancy Grimm, ${ }^{\dagger, \S}$ Krystin Riha, ${ }^{\perp, \#}$ Greg Michalski, ${ }^{\nabla}$ \\ Kathleen A. Lohse, ${ }^{\bigcirc}$ and Daniel Childers \\ ${ }^{\dagger}$ School of Life Sciences, ${ }^{\S}$ Global Institute of Sustainability, and ${ }^{\star}$ School of Sustainability, Arizona State University, Tempe, Arizona \\ 85287, United States \\ ${ }^{\ddagger}$ Global Change and Sustainability Center, University of Utah, Salt Lake City, Utah 84112, United States \\ "Institute of Hazard, Risk and Resilience, Department of Geography, Durham University, Durham DH1, U.K. \\ ${ }^{\perp}$ Department of Earth Atmospheric and Planetary Sciences, and ${ }^{\nabla}$ Department of Chemistry, Purdue University, West Lafayette, \\ Indiana 47907, United States \\ "Pacific Northwest National Laboratory, Richland, Washington 99352, United States \\ ODepartment of Biological Sciences, Idaho State University, Pocatello, Idaho 83209, United States
}

\section{Supporting Information}

\begin{abstract}
Urban watersheds are often sources of nitrogen (N) to downstream systems, contributing to poor water quality. However, it is unknown which components (e.g., land cover and stormwater infrastructure type) of urban watersheds contribute to $\mathrm{N}$ export and which may be sites of retention. In this study we investigated which watershed characteristics control $\mathrm{N}$ sourcing, biogeochemical processing of nitrate $\left(\mathrm{NO}_{3}{ }^{-}\right)$during storms, and the amount of rainfall $\mathrm{N}$ that is retained within urban watersheds. We used triple isotopes of $\mathrm{NO}_{3}^{-}\left(\delta^{15} \mathrm{~N}, \delta^{18} \mathrm{O}\right.$, and $\left.\Delta^{17} \mathrm{O}\right)$ to identify sources and transformations of $\mathrm{NO}_{3}{ }^{-}$during storms from 10 nested arid urban watersheds that varied in stormwater infrastructure type and drainage area. Stormwater infrastructure and land cover-retention basins, pipes, and grass coverdictated the sourcing of $\mathrm{NO}_{3}{ }^{-}$in runoff. Urban watersheds were strong sinks or sources of $\mathrm{N}$ to stormwater depending on runoff, which in turn was

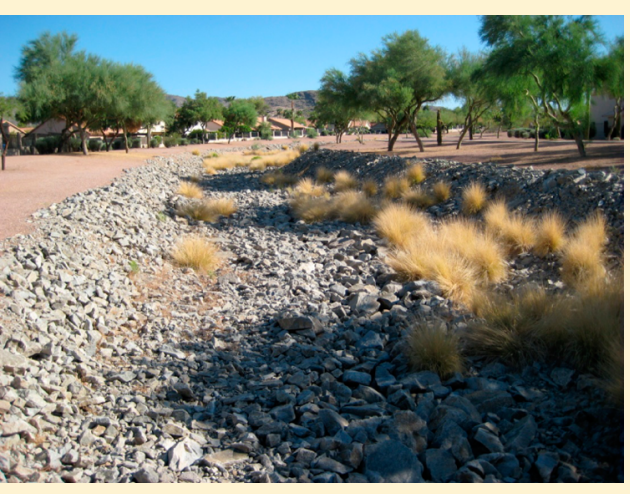
inversely related to retention basin density and positively related to imperviousness and precipitation. Our results suggest that watershed characteristics control the sources and transport of inorganic $\mathrm{N}$ in urban stormwater but that retention of inorganic $\mathrm{N}$ at the time scale of individual runoff events is controlled by hydrologic, rather than biogeochemical, mechanisms.
\end{abstract}

\section{INTRODUCTION}

Urban watersheds are often sources of nitrogen $(\mathrm{N})$ and other pollutants to downstream systems. ${ }^{1-4}$ At the same time, numerous studies have documented high rates of $\mathrm{N}$ retention in urban watersheds, ${ }^{2,5-7}$ albeit usually not as high as those of nonurban systems. Retention (here defined as the difference between inputs and watershed export ${ }^{2,7}$ ) includes internal processes such as denitrification or volatilization that result in gaseous loss of $\mathrm{N}$ from the watershed and thereby reduce the $\mathrm{N}$ load in runoff. $\mathrm{N}$ may also be retained in watersheds via immobilization in soils and/or assimilation into plant or microbial biomass, or it may simply be stored due to lack of hydrologic transport. Whatever the mechanism, it is clear that urban watersheds have some capacity to modulate pollutant loads to downstream ecosystems. However, we do not know which watershed features (e.g., land-use or cover types, stormwater infrastructure features) contribute most to $\mathrm{N}$ export and which may be sites of retention, making it difficult to manage urban nonpoint source $\mathrm{N}$ pollution.

Observed high $\mathrm{N}$ retention rates in urban watersheds have led to an effort to identify specific locations within watersheds that support high rates of $\mathrm{N}$ retention, so-called "hotspots"(sensu McClain et al. $\left.^{8}\right)$. Terrestrial ecologists have focused largely on the role of residential landscapes-yards-as potential hotspots, ${ }^{9-11}$ whereas aquatic ecologists have studied streams and stormwater infrastructure features as sites of $\mathrm{N}$ removal. ${ }^{12-19}$ The potential rates of denitrification in urban yards $^{10,11}$ and retention basins ${ }^{13,16}$ are very high, and a recent study in Tucson, AZ, found large fluxes of nitrous oxide $\left(\mathrm{N}_{2} \mathrm{O}\right)$ from urban ephemeral stream channels following wetting, ${ }^{19}$ suggesting that these systems may also be hotspots of $\mathrm{N}$ removal. However, it is not clear how the biogeochemical functioning of these systems affects $\mathrm{N}$ retention and transport at the watershed scale. Furthermore, the relative importance of yards compared with streams and stormwater infrastructure features as hotspots of $\mathrm{N}$ removal has not been determined.

Received: February 28, 2014

Revised: $\quad$ May 6, 2014

Accepted: May 6, 2014

Published: May 6, 2014 
The sources of $\mathrm{N}$ in urban stormwater are also not always well understood. Sourcing studies in mesic cities ${ }^{4,20,21}$ show that atmospheric $\mathrm{NO}_{3}{ }^{-}$and sewage or septic waste are the dominant sources of $\mathrm{NO}_{3}^{-}$in urban surface waters, ${ }^{4,20}$ but these generalizations may not apply to newer cities in arid regions. ${ }^{22}$ Deep groundwater tables in arid (relative to mesic cities) may reduce the importance of leaks from sanitary sewers as a source of $\mathrm{N}$ to streams, and hydrologic differences between cities, such as precipitation regimes and subsurface hydrology, may also alter opportunities for biogeochemical $\mathrm{N}$ transformations. Furthermore, urban landscaping in arid cities includes not only mesic lawns, but also "xeriscapes" that are planted with drought-tolerant plants. Differences in the management and ecological functioning of these systems ${ }^{11}$ may lead to patterns of $\mathrm{N}$ sources and transformations that differ from those observed in mesic cities. In addition, recent conceptual advances have suggested that urban biogeochemistry varies across scales, ${ }^{23}$ yet it is unknown how $\mathrm{N}$ sources might vary with watershed size.

Previous findings in Arizona ${ }^{24-26}$ demonstrated that stormwater $\mathrm{N}$ export is primarily a function of runoff, with biogeochemical processes playing a minor role. However, other research has found that increasing hydrologic residence time increases opportunities for biogeochemical transformations across a range of ecosystem scales from individual small streams to large watersheds. ${ }^{27-30}$ Furthermore, Hale et al. ${ }^{26}$ found that spatial and temporal patterns of event-specific $\mathrm{N}$ export can be variable. Wet $\mathrm{N}$ deposition is highly variable in both space and time; ${ }^{31}$ yet how this variability in wet $\mathrm{N}$ deposition translates to spatial and temporal patterns of stormwater $\mathrm{N}$ export has not been evaluated. Thus, the overarching aim of this study was to understand mechanisms and watershed structural controls regulating the source and retention of $\mathrm{N}$ in urban stormwater systems.

Specifically, the first question we addressed was, (Q1) At the time scale of rainfall-runoff events, how much dissolved inorganic $\mathrm{N}$ is exported from watersheds in runoff compared to $\mathrm{N}$ inputs via rainfall? To determine the extent to which $\mathrm{N}$ exported in flow is derived directly from precipitation, we then asked, (Q2) What are the sources and transformations of stormwater $\mathrm{NO}_{3}{ }^{-}$in arid urban watersheds? To refine further our understanding of variability in sources of stormwater $\mathrm{NO}_{3}{ }^{-}$, we asked, (Q3) Which watershed features (land cover and stormwater infrastructure) are important in determining source characteristics?

\section{METHODS}

Study Site. N sourcing and retention were evaluated in the Central Arizona-Phoenix Long-Term Ecological Research (CAP LTER) study area, located in the Phoenix, AZ, metropolitan region (hereafter Phoenix). Phoenix is a rapidly growing urban area with a population of $\sim 4.3$ million and an extensively modified hydrologic system. ${ }^{32-35}$ It is located in the Sonoran Desert, where the climate is hot and dry. Precipitation averages $180 \mathrm{~mm}$ annually, but ranges widely within and between years. On average, about half of the annual rainfall falls during the summer monsoon season, and half falls during the passages of winter frontal storm systems. Summer convective storms have intense localized rainfall, whereas winter storms tend to feature longer duration, low-intensity rains over broader areas.

Stormwater in Phoenix, as in other cities, is managed with a variety of stormwater infrastructure designs, including storm sewers, engineered open channels, and retention basins. We sampled rain and runoff from 10 nested urban watersheds that varied in stormwater infrastructure type and drainage area (see Hale et al. ${ }^{26}$ and Supporting Information for site information and descriptions of infrastructure designs). Because of the arid climate, these watersheds do not have baseflow and produce runoff only in response to rain. Land use in the seven smallest watersheds was characterized as predominately residential; these watersheds differed in area and stormwater infrastructure design. The two smallest watersheds (6-10 ha) were drained by surface drainage by streets only. The other five small watersheds ranged from 18 to 141 ha in size and were drained primarily by pipes, engineered channels, or retention basins. The three largest watersheds (1662-20247 ha) had a mix of land uses (residential, commercial, industrial, and open desert) and stormwater infrastructure types, and are herein referred to as "integrator" watersheds.

Event N Retention. Stormwater and precipitation samples were collected for all storm events from August 2010 to August 2012. Detailed methods for estimating retention of dissolved inorganic $\mathrm{N}$ (DIN) for each event can be found in the Supporting Information. Automated pump samplers [ISCO (Lincoln, Nebraska, USA)] were used to collect discrete stormwater samples from the outlet of each watershed during storm events. Stage height was monitored using ISCO 730 bubbler modules. Rainfall for discrete rainfall events was collected in acid-washed, 1-L bottles fitted with a funnel and stopper that were colocated with pump sampler locations and deployed immediately prior to storms. Rainfall samples were collected for 4 events for which there was the best coverage of sites: 5 Nov 2011, 7 Nov 2011, 13 Dec 2011, and 30 Jul 2012, enabling us to estimate event-scale DIN budgets across the watersheds. Rainfall and runoff samples were centrifuged to remove particulate material and analyzed for $\mathrm{NH}_{4}{ }^{+}$and $\mathrm{NO}_{3}{ }^{-}$ using a Lachat Quick Chem 8000 flow injection analyzer.

Event-scale DIN retention was then calculated as a proportion:

$$
\text { retention }_{\mathrm{DIN}}=\frac{\left(\mathrm{DIN}_{\text {rainfall }}-\mathrm{DIN}_{\text {runoff }}\right)}{\mathrm{DIN}_{\text {rainfall }}}
$$

where the DIN load in rainfall was calculated by multiplying the rainfall DIN concentration by watershed area and rainfall depth, and the runoff DIN was calculated by multiplying the DIN concentrations in runoff (extrapolated over the hydrograph from time-discrete measurements) by discharge (Hale et al.; ${ }^{26}$ further detail on methods used in the Supporting Information).

Isotopic Analysis. Analysis of $\mathrm{N}$ and $\mathrm{O}$ isotopes of $\mathrm{NO}_{3}{ }^{-}$ was performed on water from three storms, 5 Oct 2010, 7 Nov 2011, and 13 Dec 2011, during which the majority of the watersheds flowed. These rainfall $(N=21)$ and stormwater $(N$ $=180)$ samples were filtered through ashed Whatman GF/F filters and frozen immediately. We also collected soil and impervious-surface samples for $\mathrm{NO}_{3}{ }^{-}$isotopic analysis (see Supporting Information for details). Briefly, $5 \mathrm{~cm}$ deep soil cores were sieved to $2 \mathrm{~mm}$ and extracted with nanopure water. To characterize $\mathrm{N}$ sources from impervious surfaces, a smalldiameter $\left(470 \mathrm{~cm}^{2}\right)$ PVC ring fitted with foam tape was used to create a temporary seal with concrete (i.e., sidewalks) and asphalt surfaces (i.e., roads). Then, $1 \mathrm{~L}$ of deionized water was added and agitated to ensure dissolution of any soluble material that had accumulated on the surface. The resulting solution was collected using a peristaltic pump. These water samples were 
transported on ice to the laboratory where they were processed using the same protocols as for stormwater runoff.

Frozen water samples were shipped on ice to the Purdue Stable Isotope Facility for isotopic analysis of $\mathrm{NO}_{3}^{-}\left(\delta^{18} \mathrm{O}\right.$, $\delta^{17} \mathrm{O}$, and $\left.\delta^{15} \mathrm{~N}\right)$ using the denitrifier gold-tube thermalreduction method. ${ }^{36-38} \mathrm{NO}_{3}^{-}$was denitrified to $\mathrm{N}_{2} \mathrm{O}$ by a pure culture of denitrifying bacteria. The $\mathrm{N}_{2} \mathrm{O}$ samples were then thermally decomposed into $\mathrm{N}_{2}$ and $\mathrm{O}_{2}$, which were subsequently analyzed for $\delta^{15} \mathrm{~N}, \delta^{17} \mathrm{O}$, and $\delta^{18} \mathrm{O}$ on a Delta $\mathrm{V}$ Plus Thermo-Finnegan isotope ratio mass spectrometer. We report $\delta^{15} \mathrm{~N}$ relative to air- $\mathrm{N}_{2}$, and $\delta^{17} \mathrm{O}$ and $\delta^{18} \mathrm{O}$ relative to the Vienna Standard Mean Ocean Water (VSMOW), where

$$
\delta=\left(R_{\text {sample }} / R_{\text {standard }}-1\right) 1000
$$

and $R$ is the ratio of the heavy to light isotope of the sample and the known standard. Precision of the $\delta^{15} \mathrm{~N}$ values was $\pm 0.4 \%$, for $\delta^{18} \mathrm{O} \pm 1.0 \%$, and for $\delta{ }^{17} \mathrm{O} \pm 0.3 \%$, based on replicate analysis of the working standards and calibrations.

Isotope mixing analysis was used to determine the fraction (f) of stormwater $\mathrm{NO}_{3}{ }^{-}$from atmospheric, fertilizer, and nitrified soil sources: $f_{\text {atm }}+f_{\text {fert }}+f_{\text {nit }}=1 . \Delta^{17} \mathrm{O}$ values were used to estimate the fractional contribution of atmospheric $\mathrm{NO}_{3}{ }^{-}$ $\left(f_{\text {atm }}\right)$ to stormwater. Atmospheric $\mathrm{NO}_{3}{ }^{-}$is anomalously enriched in ${ }^{17} \mathrm{O}$ as a result of ${ }^{17} \mathrm{O}$-enriched ozone that is then transferred to $\mathrm{NO}_{3}^{-}$during the oxidation of $\mathrm{NO}_{x}{ }^{39,40}$ The difference between the $\delta^{17} \mathrm{O}$ value predicted by mass-dependent biological fractionation (described by relationship: $\delta^{17} \mathrm{O}=$ $\left.0.52\left(\delta^{18} \mathrm{O}\right)\right)$ and the $\delta^{17} \mathrm{O}$ value of atmospheric $\mathrm{NO}_{3}{ }^{-}$is positive and is denoted $\Delta^{17} \mathrm{O} .{ }^{39} \Delta^{17} \mathrm{O}$ values are conserved during mass-dependent fractionation (e.g., during denitrification) and can be used as a tracer of atmospheric $\mathrm{NO}_{3}{ }^{-}$ deposition. The $f_{\text {atm }}$ was estimated using ${ }^{39-41}$

$$
f_{\text {atm }}=\frac{\Delta^{17} \mathrm{O}_{\text {sample }}}{\Delta^{17} \mathrm{O}_{\text {atmosphere }}}
$$

The runoff $\mathrm{NO}_{3}{ }^{-}$isotopic values were transformed using $f_{\text {atm }}$ to remove the atmospheric $\mathrm{NO}_{3}{ }^{-} \delta^{15} \mathrm{~N}$ and $\delta^{18} \mathrm{O}$ contribution in the runoff $\mathrm{NO}_{3}{ }^{-}$following the methods of Dejwakh et al.: ${ }^{41}$

$$
\begin{aligned}
& \delta^{18} \mathrm{O}_{\text {trans }}=\left(\delta^{18} \mathrm{O}_{\text {runoff }}-f_{\text {atm }}\left(\delta^{18} \mathrm{O}_{\mathrm{atm}}\right)\right) /\left(1-f_{\mathrm{atm}}\right) \\
& \delta^{15} \mathrm{~N}_{\text {trans }}=\left(\delta^{15} \mathrm{~N}_{\text {runoff }}-f_{\mathrm{atm}}\left(\delta^{15} \mathrm{~N}_{\mathrm{atm}}\right)\right) /\left(1-f_{\mathrm{atm}}\right)
\end{aligned}
$$

where $\delta^{18} \mathrm{O}_{\text {trans }}$ and $\delta^{15} \mathrm{~N}_{\text {trans }}$ are the isotopic values with the atmospheric signal removed and $\delta^{15} \mathrm{~N}_{\mathrm{atm}}$ and $\delta^{18} \mathrm{O}_{\mathrm{atm}}$ are the average isotopic values of rainfall $\mathrm{NO}_{3}{ }^{-}$.

A second mixing model was used to separate the fractions of fertilizer $\mathrm{NO}_{3}{ }^{-}$(hereafter $\mathrm{NO}_{3}{ }^{-}$fert $)$and microbially nitrified $\mathrm{NO}_{3}{ }^{-}$(hereafter $\mathrm{NO}_{3}{ }^{-}$nit $)$:

$$
f_{\text {fert }}=\left(1-f_{\text {atm }}\right) \times \frac{\left(\delta^{18} O_{\text {trans }}-\delta^{18} O_{\text {soil }}\right)}{\left(\delta^{18} O_{\text {fert }}-\delta^{18} O_{\text {soil }}\right)}
$$

where $f_{\text {fert }}$ is the fractional contribution of fertilizer to runoff $\mathrm{NO}_{3}{ }^{-}$as a fraction. The fractional contribution of $\mathrm{NO}_{3}{ }^{-}$nit $\left(f_{\text {nit }}\right)$ was calculated by difference $\left(1-\left(f_{\mathrm{atm}}+f_{\text {fert }}\right)\right)$. An average $\delta^{18} \mathrm{O}$ value of $21 \%$ for $\mathrm{NO}_{3}{ }^{-}{ }_{\text {fert }}^{4}$ and the average measured $\delta^{18} \mathrm{O}$ of soil $\mathrm{NO}_{3}{ }^{-}$were used as isotope end-members in the mixing model. We assessed the sensitivity of our results to the $\delta^{18} \mathrm{O}$ value of fertilizer by also assessing the model for the minimum (17\%) and maximum (25\%) reported $\delta^{18} \mathrm{O}$ values for $\mathrm{NO}_{3}{ }^{-}$ fertilizer.
All hydrological and chemical data from this research will be available on the CAP LTER Web site: caplter.asu.edu/data.

Statistical Analysis. All data were transformed as needed to meet assumptions of normality and homogeneity of variance. One-way analysis of variance (ANOVA) was used to test for differences in isotopic composition of $\mathrm{NO}_{3}{ }^{-}$across different source types (rain, mesic, xeric, concrete, asphalt). To understand watershed controls on $\mathrm{NO}_{3}^{-}$sources, we used multiple linear regression to characterize relationships between land cover (\% impervious, grass, and soil cover), stormwater infrastructure (density of retention basins, pipes, and channels), storm variables (runoff coefficient, storm duration, rain-free and flow-free days preceding the event, and rain depth) and the proportion of $\mathrm{NO}_{3}{ }^{-}$sources $\left(f_{\text {atm }}, f_{\text {fert }} f_{\text {nit }}\right)$ in stormwater runoff. Pearson correlation was used to determine the relationship between $\delta^{18} \mathrm{O}$ values and $\delta^{15} \mathrm{~N}$ values of $\mathrm{NO}_{3}{ }^{-}$ within events. All statistical analyses were conducted in $\mathrm{R}$ version 2.15.1 (www.r-project.org).

\section{RESULTS AND DISCUSSION}

Urban Watersheds Can Be Strong Sinks or Sources of $\mathbf{N}$ to Stormwater. Inputs of DIN in rainfall varied considerably across sites and events, ranging from $0.02 \mathrm{~kg} / \mathrm{ha}$ to $0.32 \mathrm{~kg} / \mathrm{ha}$, and total event DIN export also ranged widely, from $<0.001$ to $0.78 \mathrm{~kg} \mathrm{DIN} /$ ha (Figure 1). Most of the study watersheds were sinks for $\mathrm{N}$ at the time scale of discrete
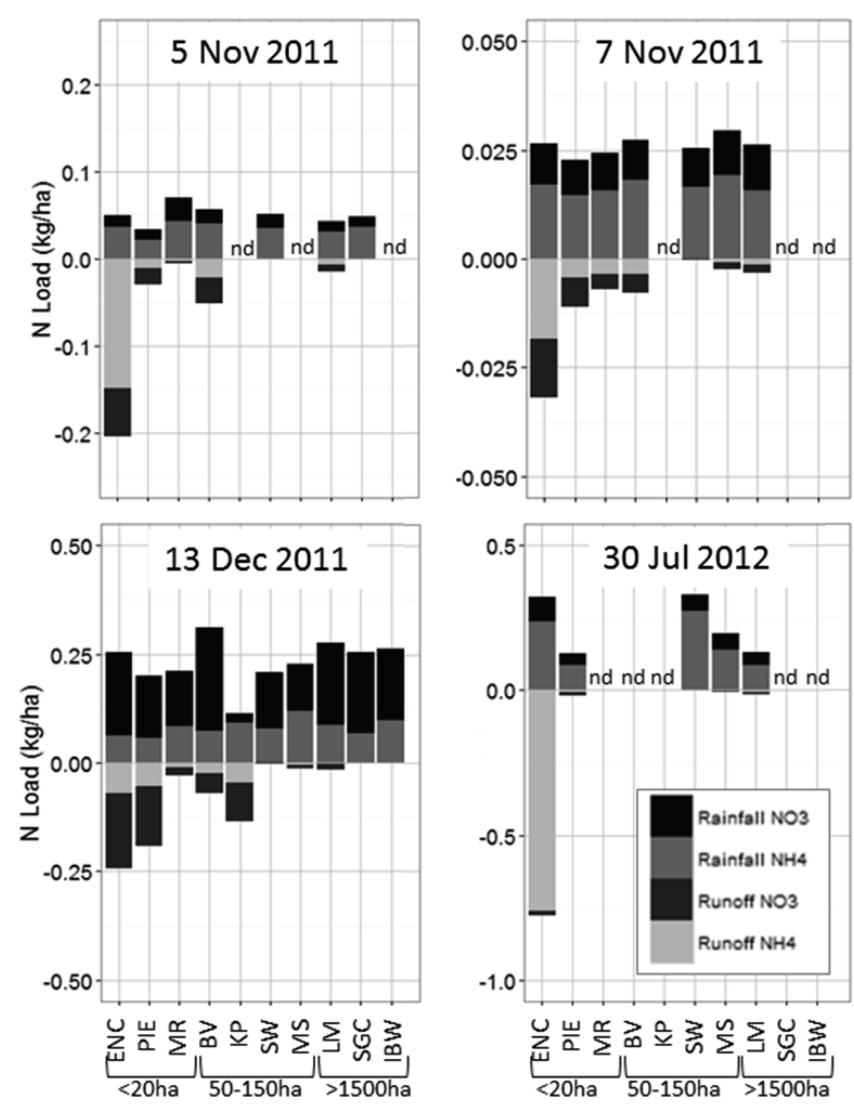

Figure 1. Inputs of DIN in rainfall (positive values) and outputs in runoff (negative values) for each site during four storms. Note that fluxes for each event are not plotted on the same scale. Events for which there was no runoff, and therefore no data are indicated by "nd." Note that for events with no runoff data, rainfall data are not shown. Sites are arranged by drainage area. 
rainfall-runoff events, although the pipe- and surface-drained watersheds were sometimes sources of $\mathrm{N}$ downstream (Q1). Study watersheds were sinks rather than sources of DIN in 25 out of 29 events. DIN retention ranged from $-314 \%$ to nearly $100 \%$ of rainfall inputs.

To our knowledge, these retention rates are the first reported at rainfall-runoff event time scales in urban watersheds, and some of the highest reported in the literature for urban watersheds across all time scales. Event $\mathrm{N}$ balances in the study watersheds reported here were also more variable than previous measures of urban watershed-scale $\mathrm{N}$ retention, varying in both the order of magnitude of retention as well as the sign (e.g., source vs sink). By comparison, annual $\mathrm{N}$ retention in suburban watersheds of the Northeast ranged from 35 to $85 \%$ of annual inputs. $^{2,4,6,7}$

Much of the variation in DIN retention was due to variation in runoff, as has been observed at annual scales. ${ }^{4,7}$ The proportion of DIN retained by each watershed was significantly related to the event runoff coefficient (runoff/precipitation; analysis of covariance (ANCOVA), $F_{(1,25)}=28.72, p<0.0001$ ), and there was a significant interaction with the number of noflow days preceding the storm (ANCOVA: $F_{(1,25)}=5.231, p=$ 0.03 , Figure 2), although no-flow days alone was not a

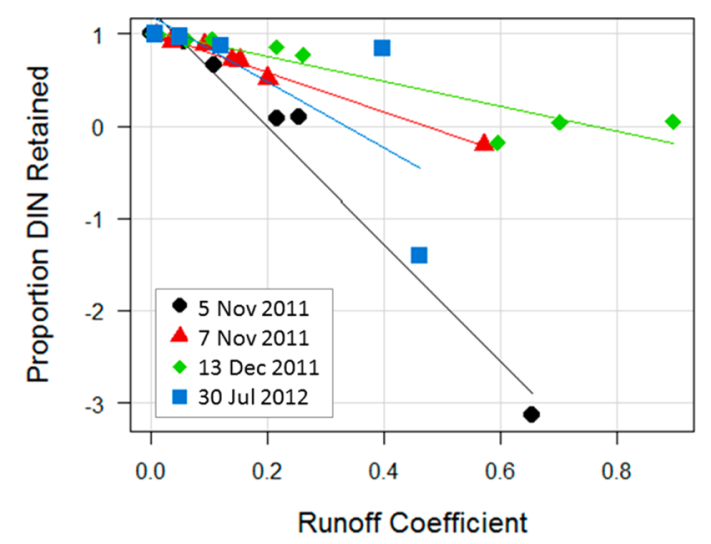

Figure 2. Proportion of DIN retained by each watershed was significantly related to runoff coefficient (ANCOVA, $F_{(1,25)}=28.72, p$ $<0.0001$ ), and there was a significant interaction with the number of no flow days preceding the storm (ANCOVA: $F_{(1,25)}=5.231, p=$ $0.03)$.

significant predictor (ANCOVA: $F_{(1,25)}=2.199, p=0.15$ ). The interaction with antecedent conditions, the number of days with no flow preceding the event, was such that retention was decreased by increasing no flow days. This suggests that drier antecedent conditions allow accumulation of $\mathrm{N}$ within the watershed, providing more sources of $\mathrm{N}$ to stormwater and reducing overall retention.

Watersheds with runoff coefficients greater than $\sim 0.45$ tended to be weak sinks or even sources depending on the site and the event. Runoff coefficients in these study watersheds, in turn, were strongly and negatively related to retention basin density and watershed area and positively related to impervious cover and precipitation. ${ }^{26}$ In these watersheds, therefore, retention basin density was associated with increased DIN retention at the watershed scale, whereas the imperviousness and precipitation was associated with decreased DIN retention at the watershed scale. Larger watersheds also had lower runoff coefficients and therefore retained more DIN, as noted by Lewis and Grimm. ${ }^{43}$
Sources of $\mathrm{NO}_{3}{ }^{-}$in Urban Stormwater. The isotopic composition of $\mathrm{NO}_{3}^{-}$varied significantly across rainfall, soil, and impervious surfaces (Figure 3). Values of $\delta^{15} \mathrm{~N}^{-\mathrm{NO}_{3}}{ }^{-}$

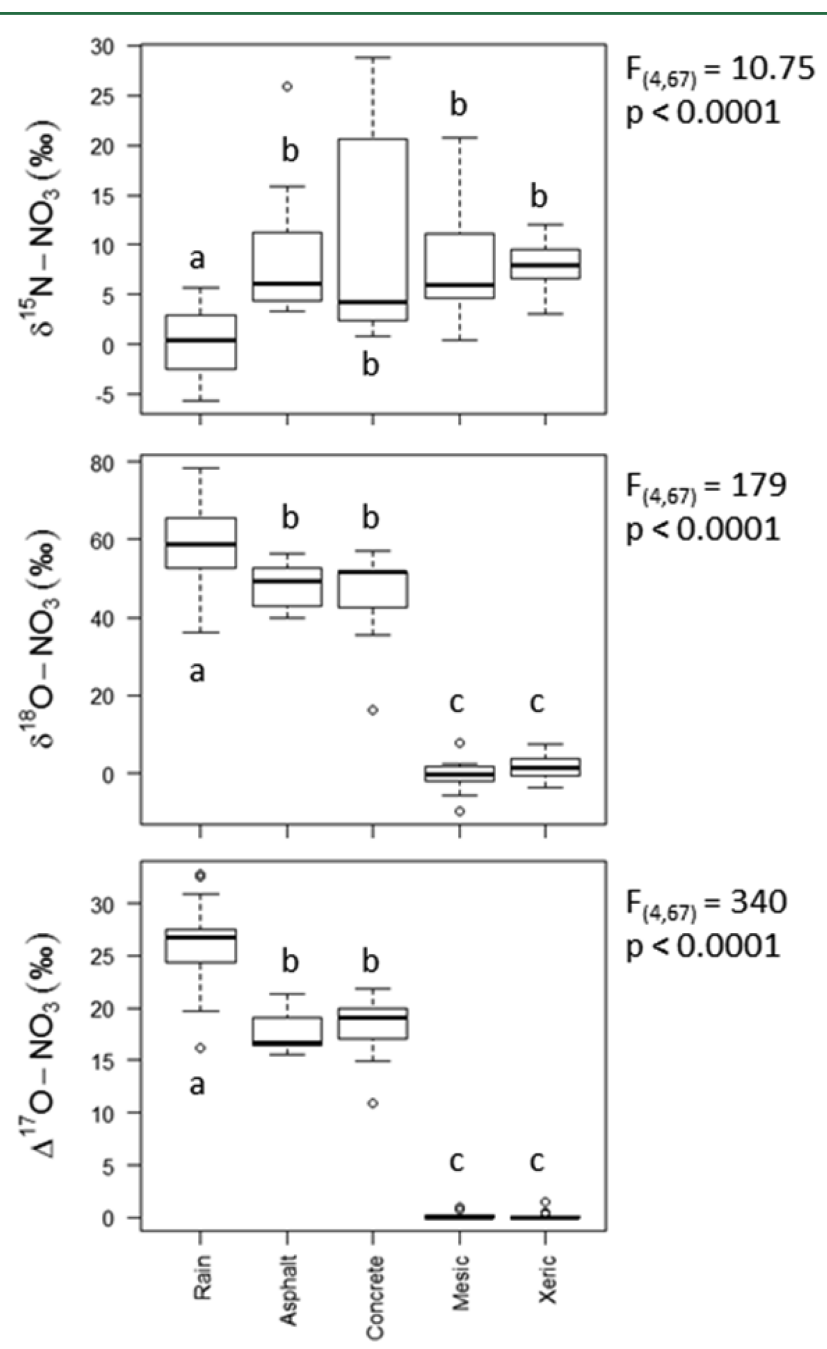

Figure 3. Isotopic characteristics of $\mathrm{NO}_{3}{ }^{-}$in rainfall and other potential sources within watersheds. Statistics are results from one-way analysis of variance (ANOVA). Boxes with different letters are significantly different at $p<0.05$ using Tukey's (honestly significant differences) HSD test. Mesic indicates yards with turf grass, while Xeric indicates xeriscaped yards (i.e., low water use plants).

varied among source types, with higher $\delta^{15} \mathrm{~N}$ values in soil and impervious surfaces (potential watershed sources) than in rain (Figure 3, Supporting Information). Values of $\delta^{18} \mathrm{O}$ and $\Delta^{17} \mathrm{O}$ of $\mathrm{NO}_{3}{ }^{-}$in rainfall were significantly higher than both impervious surface and soil sources (Figure 3). Within watersheds, $\mathrm{NO}_{3}{ }^{-}$collected from impervious surfaces had the highest $\delta^{18} \mathrm{O}$ and $\Delta^{17} \mathrm{O}$ values. The isotopic composition of $\mathrm{NO}_{3}{ }^{-}$from xeric and mesic yards did not differ (Figure 3).

Isotopic evidence suggests that fertilizer, atmospheric, and microbial sources all contribute to $\mathrm{NO}_{3}{ }^{-}$in stormwater (Figure 4). Overall, fertilizer was the largest source of $\mathrm{NO}_{3}^{-}$in stormwater, contributing from 6 to $65 \%$ of stormwater runoff $\mathrm{NO}_{3}{ }^{-}$loads (44\% on average; Figure 5). These values are very high compared to other urban studies that have found fertilizer to be only a minor component of stormwater $\mathrm{NO}_{3}{ }^{-4,20,44}$ The contribution of fertilizer $\mathrm{NO}_{3}{ }^{-}$was not strongly sensitive to the $\delta^{18} \mathrm{O}$ value of fertilizer chosen. The mean fertilizer contribution 

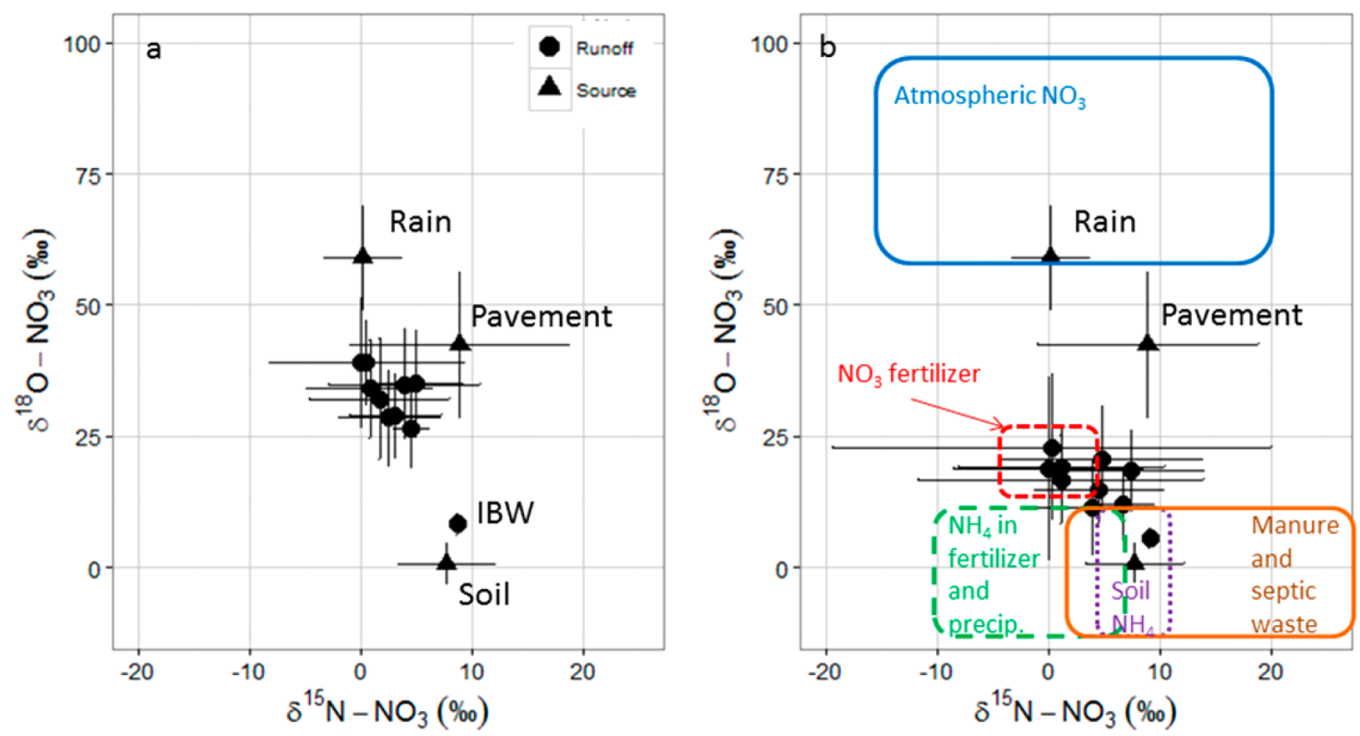

Figure 4. Dual isotope plot of means and standard deviations across all soil, rainfall, and runoff samples across all events: (a) untransformed means and standard deviations. In plot $\mathrm{b}$, runoff data have been transformed to remove atmospheric signal. Ranges of $\delta^{15} \mathrm{~N}$ and $\delta^{18} \mathrm{O}$ values are shown (from Kendall 2007).

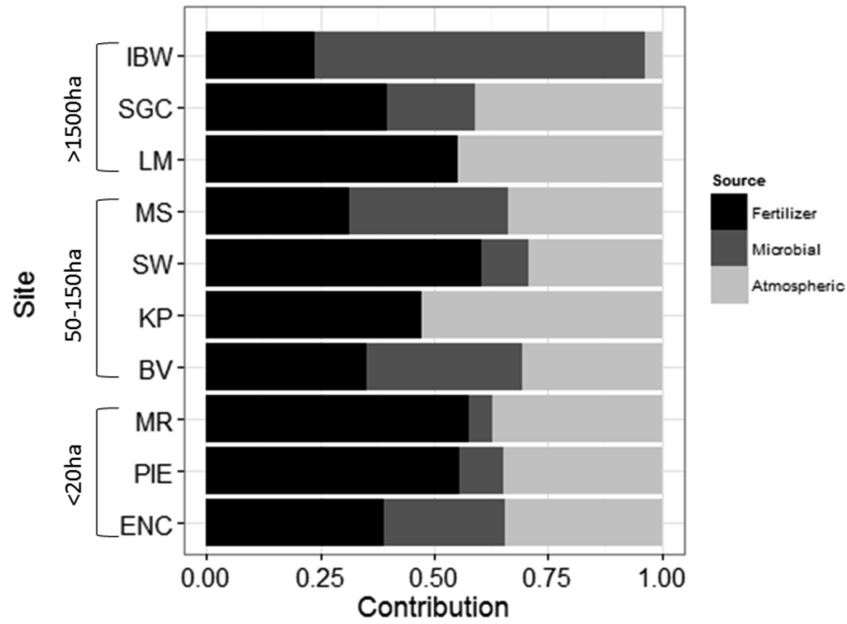

Figure 5. Mean fractional contribution of different $\mathrm{NO}_{3}{ }^{-}$sources to stormwater $\mathrm{NO}_{3}{ }^{-}$for each watershed. Sites $(y$-axis) are arranged by drainage area. See Supporting Information for site abbreviations and descriptions.

ranged from $38 \%$ to $50 \%$ depending on the $\delta^{18} \mathrm{O}$ value used. We attribute the high $\mathrm{NO}_{3}^{-}$fert contribution to very high amounts of fertilizer used in Phoenix: annual fertilizer $\mathrm{N}$ inputs, estimated at $223 \mathrm{~kg} \mathrm{~N}$ ha lawn ${ }^{-1} \mathrm{y}^{-1}$ by Baker et al., ${ }^{5}$ are likely 1 to 2 orders of magnitude higher than those from atmospheric deposition. Assuming that $50 \%$ of all pervious areas are fertilized, ${ }^{5}$ this would be the equivalent of 69 to $130 \mathrm{~kg} \mathrm{~N} \mathrm{ha}^{-1}$ $\mathrm{y}^{-1}$ input via fertilization, an order of magnitude larger than estimates of total annual $\mathrm{N}$ deposition of $<6$ to $18 \mathrm{~kg} / \mathrm{ha} .{ }^{45,46}$ As in previous studies, ${ }^{4,20,47,48}$ we found that $f_{\text {atm }}$ in urban stormwater was high, averaging $34 \%$. The contribution of $\mathrm{NO}_{3}{ }^{-}$ to total $\mathrm{NO}_{3}{ }^{-}$atm export from watersheds ranged from 4 to $53 \%$ across all observed events (Figure 5), and observations of $f_{\text {atm }}$ for individual samples within events ranged much more widely ( 0 to $80 \%$ over all samples). Previous work has found that while wastewater is a major source of $\mathrm{N}$ to urban baseflow, atmospheric sources tend to dominate during storms, ${ }_{4,20,44,47}$ which, due to the absence of baseflow, was the only component of flow measured in this study. This pattern of increased $f_{\text {atm }}$ under high flows is common across climates and land-use types. ${ }^{44,48-51}$ A review by Curtis et al. ${ }^{51}$ found that $\mathrm{NO}_{3}{ }^{-}$atm could comprise up to $100 \%$ of stream $\mathrm{NO}_{3}{ }^{-}$in forested watersheds during high-flow and snowmelt events. In other urban watersheds, $f_{\text {atm }}$ ranges widely, but has been observed to contribute up to $94 \%$ of $\mathrm{NO}_{3}{ }^{-}$in streamflow during storms. ${ }^{4}$

Microbially nitrified $\mathrm{NO}_{3}{ }^{-}$contributed an average of $24 \%$ of $\mathrm{NO}_{3}{ }^{-}$in stormwater runoff, though this source varied across events and sites as well (range $=0$ to $75 \%$; Figure 5). The largest microbial contribution to stormwater $\mathrm{NO}_{3}^{-}$(75\%) was observed at the largest watershed scale (20247 ha), in the Indian Bend Wash watershed. All other watersheds had $f_{\text {nit }}$ between 0 and $38 \%$. Although the $f_{\text {nit }}$ was small relative to fertilizer and atmospheric sources for most watersheds, the presence of microbially nitrified $\mathrm{NO}_{3}{ }^{-}$suggests active biogeochemical processing in these urban watersheds. Evidence discussed below suggests these microbially mediated biogeochemical transformations occur between, rather than during, events.

$\mathrm{NO}_{3}{ }^{-}$Sources Are Related to Land Cover and Infrastructure, Not Hydrologic Factors. The contribution of $\mathrm{NO}_{3}{ }^{-}$from atmospheric and microbial sources was significantly related to land cover and stormwater infrastructure characteristics, but not to storm characteristics. The contribution of $\mathrm{NO}_{3}^{-}$fert was not significantly related to any watershed or storm characteristics. Although fertilizer use is likely related to pervious cover, the timing of fertilizer applications may vary within a watershed, obscuring any relationship between land cover and $f_{\text {fert }}$. Unlike previous studies, ${ }^{20,44,47,52}$ we did not find a significant relationship between $f_{\text {atm }}$ and total or connected impervious surface cover. We did find, however, that \% grass and the density of retention basins were inversely correlated with $f_{\text {atm }}$. The maximum observed $f_{\text {atm }}$ within an event was significantly and negatively related to the amount of grass cover within a watershed $\left(R^{2}=0.44, p=0.002\right)$, but was not significantly related to any other watershed or storm characteristics. The $f_{\text {atm }}$ of total event $\mathrm{NO}_{3}{ }^{-}$loads, however, was significantly and negatively related to the density of retention 


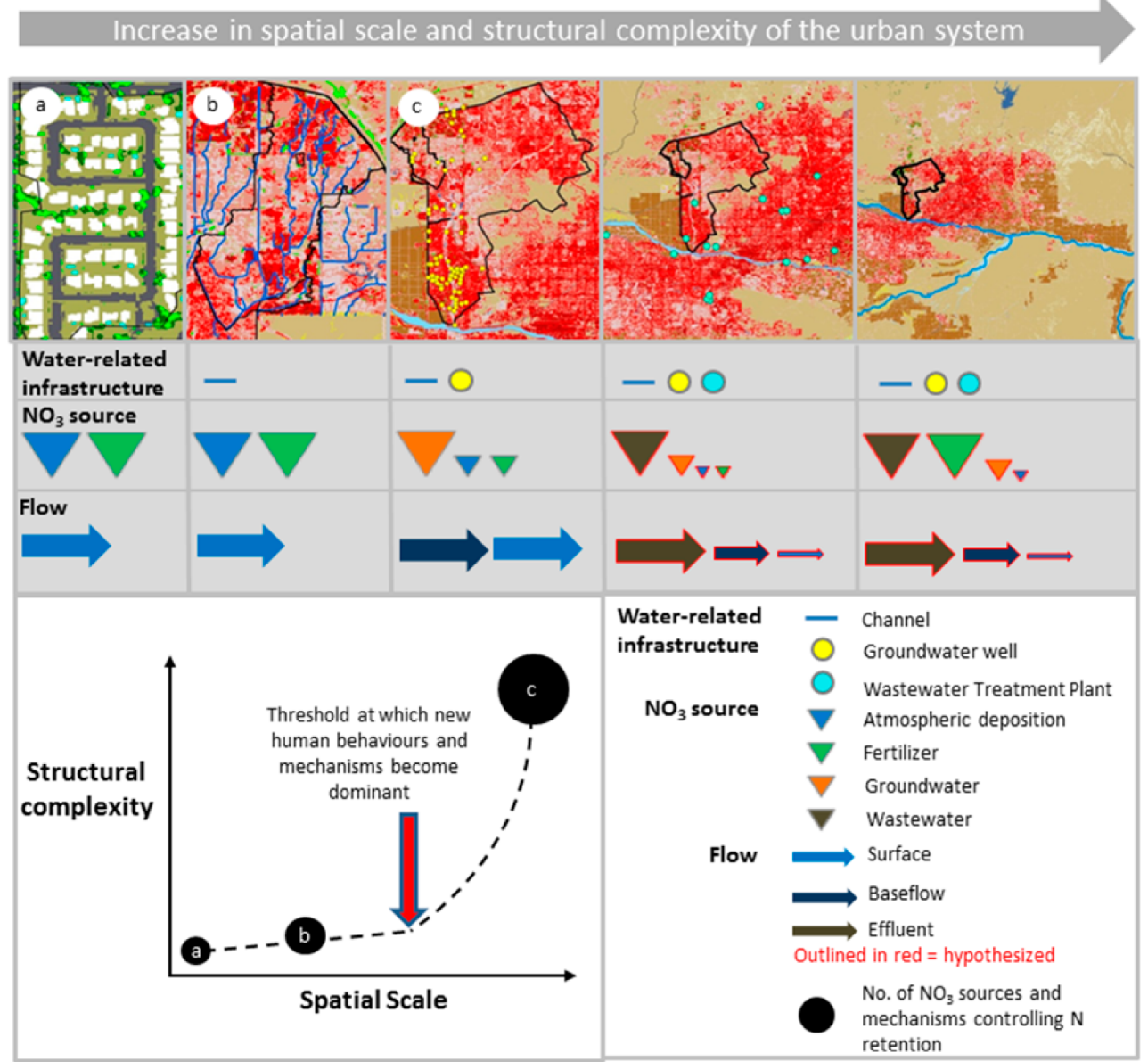

Figure 6. Illustration of observed and hypothesized changes in $\mathrm{NO}_{3}{ }^{-}$sources across scales in Phoenix watersheds.

basins and significantly and positively related to the density of pipes within a watershed (multiple regression: total $R^{2}=0.49, p$ $=0.004)$. This result suggests that grass cover and retention basins either remove $\mathrm{NO}_{3}{ }^{-}$atm , or that $\mathrm{NO}_{3}{ }^{-}$from other sources (fertilizer or microbial nitrification) mask the atmospheric fraction. The positive relationship between $f_{\text {atm }}$ and pipe density suggests that pipes act as inactive conduits between impervious surfaces and watershed outlets and reduce opportunities for both $\mathrm{NO}_{3}{ }^{-}$transformations and the introduction of additional $\mathrm{NO}_{3}{ }^{-}$sources.

Previous work has suggested that impervious areas act as collectors of atmospheric deposition and should therefore be good predictors of atmospheric $\mathrm{NO}_{3}{ }^{-}$contribution. ${ }^{20,44,47,52}$ In contrast, our results suggest that grass cover and stormwater infrastructure together influence $f_{\text {atm }}$ in stormwater. Atmospheric $\mathrm{NO}_{3}^{-}$deposition to yards is dwarfed by inputs of fertilizer $\mathrm{N}$, which dilutes the atmospheric signal. However, despite much greater inputs to yards, the amount of $\mathrm{NO}_{3}{ }^{-}$ stored in topsoil was less than amount stored on impervious surfaces (Supporting Information, Figure S2). Our results suggest that the high rates of denitrification documented in yards $^{9-11,15}$ and stormwater retention basins ${ }^{13,17,35}$ rapidly consume the anthropogenic inputs of $\mathrm{NO}_{3}{ }^{-}$, thus altering its isotopic composition.

Whereas $f_{\text {atm }}$ was lower in watersheds with high retention basin density, the contribution of $\mathrm{NO}_{3}{ }^{-}$nit to stormwater $\mathrm{NO}_{3}{ }^{-}$ loads was positively correlated with the density of retention basins within watersheds $\left(R^{2}=0.37, p=0.006\right)$. This result provides further evidence that these stormwater features are important sites of biogeochemical activity. Although recent work in Tucson, AZ, has demonstrated that ephemeral urban channels are biogeochemical hotspots, ${ }^{18,19,24}$ we did not find a relationship between channel density and $f_{\text {nit }}$.

No Evidence of Denitrification Occurring during Runoff Events. We found no isotopic evidence of denitrification during rainfall-runoff events, suggesting that $\mathrm{NO}_{3}{ }^{-}$retention at the event scale is via hydrologic mechanisms. A significant positive relationship between $\delta^{15} \mathrm{~N}_{-} \mathrm{NO}_{3}{ }^{-}$and $\delta^{18} \mathrm{O}-\mathrm{NO}_{3}{ }^{-}$values would indicate denitrification; ${ }^{42}$ no such relationship was found. At the two surface-drained watersheds there were significant negative correlations between $\delta^{15} \mathrm{~N}$ and $\delta^{18} \mathrm{O}(\rho=-0.87, p<0.05$ and $\rho=-0.63, p<0.05)$ during the 13 December 2011 event. These results support findings from other studies suggesting that variation in $\mathrm{NO}_{3}{ }^{-}$isotopes in urban $^{4,20,47,48,50,53}$ and nonurban ${ }^{48,49}$ waters is primarily a result of the mixing of sources rather than biogeochemical processing along flowpaths during runoff events. Across a range of land uses, isotopic evidence of denitrification at the watershed scale has only been documented during baseflow conditions and is largely limited to agricultural watersheds. ${ }^{4,21,54}$ It is important to note that a lack of isotopic evidence of denitrification does not preclude its occurrence. Several previous studies have noted that heterogeneous sources of $\mathrm{NO}_{3}{ }^{-}$can obscure signals of denitrification, ${ }^{21,52}$ and the wide variety of landscape management practices within our study watersheds would likely mask any isotopic signals of denitrification during events. That said, isotopic evidence of denitrification was documented in a 
suburban watershed ${ }^{4}$ with similar land cover to our study watersheds (though in a different climate).

These results are in contrast to previous studies that have identified yards, ${ }^{11}$ retention basins, ${ }^{13,35}$ and channels ${ }^{18,19}$ as hotspots of biogeochemical activity. It may be that these biogeochemical retention mechanisms are small relative to hydrologic retention mechanisms during runoff events due to retention of most rainfall in some watersheds (Figure 2). Alternatively, retention mechanisms, such as denitrification, may be balanced by processes that increase the availability of $\mathrm{N}$, or biogeochemical transformations may not be spatially or temporally consistent enough to observe at the watershed scale. For example, Gallo et al. ${ }^{18}$ found that grass-lined channels had highly variable source-sink dynamics during runoff events and were a source of solutes in nearly half of the observations. In another Tucson study, pervious channel density was associated with decreases in $\mathrm{NO}_{2}{ }^{-}$and $\mathrm{NH}_{4}{ }^{+}$concentrations but had no relationship with $\mathrm{NO}_{3}{ }^{-}$or dissolved organic $\mathrm{N}$ concentrations. ${ }^{24}$ However, biogeochemical processes that are triggered by rainfall events may be sustained for extended periods of time after events, ${ }^{19}$ suggesting that gaseous $\mathrm{N}$ losses may be significant between events even if they do not affect concentrations of $\mathrm{N}$ in stormwater.

Sources and Transport of Stormwater $\mathrm{NO}_{3}{ }^{-}$across Scales. The largest study watershed, Indian Bend Wash (IBW), differed substantially from the others in its isotopic composition of $\mathrm{NO}_{3}{ }^{-}$. Nitrate in IBW was dominated by $\mathrm{NO}_{3}{ }^{-}$nit $(75 \%)$, with some contribution from fertilizer and very little $\mathrm{NO}_{3}{ }^{-}$atm (Figure 5). The sampling location for IBW is located below a large flood-management system that includes a lake and stream system and a large grassy floodplain. ${ }^{34}$ Between storms, the lakes are kept filled by pumping groundwater. ${ }^{34}$ It is likely that this groundwater contributes to stormwater, an interpretation that is consistent with the very high concentrations of $\mathrm{NO}_{3}{ }^{-}$observed at IBW during the 13 December 2011 event compared to rainwater and runoff from all other watersheds (data not shown). The isotopic signature of $\mathrm{NO}_{3}{ }^{-}$ at IBW was not only distinct, but was also much less variable than the signature of $\mathrm{NO}_{3}{ }^{-}$at the other sites, suggesting that most of the $\mathrm{NO}_{3}^{-}$was coming from a different, more homogeneous source-probably groundwater.

The dramatic difference in $\mathrm{NO}_{3}{ }^{-}$sources between IBW and the other watersheds highlights the difficulty of scaling biogeochemical results in urban watersheds. The classic River Continuum Concept (RCC) $)^{55}$ was developed to explain gradual and continuous longitudinal changes in stream and river geomorphology and ecology. An implicit assumption of this model was that small-scale observations can be scaled up to predict patterns in larger rivers. Thorp ${ }^{56}$ recently argued that concepts such as the RCC fall short because spatial heterogeneity and cross-scale interactions in watersheds create nonlinearities and thresholds that make it impossible to predict large scale patterns simply by scaling up small scale observations. Despite these failings of the RCC, the concept has been recently adapted in urban watershed systems as the Urban Watershed Continuum. ${ }^{23}$ We suggest that the issues discussed by Thorp ${ }^{56}$ are especially important in urban watersheds, where nonlinearities and thresholds are generated not only by ecological processes, but by social processes as well. As watershed scale increases in urban watersheds, the complexity and heterogeneity of human behaviors and engineered structures increases. New human behaviors emerge at larger scales that complicate our efforts to scale up smallscale observations.

In this study, $\mathrm{NO}_{3}{ }^{-}$sourcing changed nonlinearly across scales (Figure 6). $\mathrm{NO}_{3}^{-}$sources were similar across all watersheds, regardless of watershed size, but it was the introduction of a new human behavior (groundwater inputs), rather than a specific scale, that caused change in $\mathrm{N}$ biogeochemistry. If we were to move to even larger scales, we would likely find that wastewater effluent and agricultural irrigation return flow introduce new sources of $\mathrm{NO}_{3}^{-}$to flow (Figure 6). Heterogeneity in $\mathrm{NO}_{3}{ }^{-}$sources across and within urban watersheds makes it is extremely difficult to accurately scale up from small to large watershed scales.

Implications for Arid Urban Stormwater Management. The results of this study have significant implications for stormwater management in arid cities. Larson and Grimm ${ }^{35}$ reported high rates of potential denitrification in stormwater retention basins in the Phoenix area, and Hale et al. ${ }^{26}$ reported that $\mathrm{N}$ delivery was negatively related to the density of retention basins in a watershed. However, our isotopic results suggest that, even though retention basins change the isotopic composition of $\mathrm{NO}_{3}{ }^{-}$in stormwater, the mechanisms driving $\mathrm{N}$ retention at the scale of rainfall-runoff events are primarily hydrologic, not biogeochemical. This finding is particularly important because Larson and Grimm ${ }^{35}$ found differences in the potential rates of denitrification between xeric and grassy retention basins and suggested that grassy retention basins may be more effective at removing $\mathrm{N}$ from stormwater than xeric basins. Retention basin landscaping may be important for understanding the fate of $\mathrm{N}$ once it has been retained in a basin. It is unclear whether $\mathrm{N}$ retained during storm events leaches into the soil (possibly creating a groundwater pollution problem), remains stored in the retention basins (to possibly be transported in subsequent storm events), is assimilated into vegetation, or is converted to $\mathrm{N}$ gases (which may or may not be greenhouse gases). ${ }^{18,19}$ That retention basins change the sources of $\mathrm{NO}_{3}{ }^{-}$but not the amount in stormwater suggests that these features are biogeochemically active between events, but not necessarily in ways that are relevant for stormwater quality protection at rainfall-runoff event time scales. Our results, in demonstrating the importance of hydrology as a control on stormwater $\mathrm{N}$ delivery, suggest that these differences in retention basin landscaping and biogeochemistry may not matter at the watershed scale, as long as the basins retain water.

\section{ASSOCIATED CONTENT}

\section{Supporting Information}

Detailed descriptions of study site and methods. Table S1, characteristics of study watersheds; Table S2, mean (standard deviation) of rainfall characteristics across the reported events and rainfall depth across all storm events measured from August 2010 to August 2012; Table S3, mean (standard deviation) of isotope values for all sites across all events. Figure $\mathrm{S} 1$, location of study watersheds; Figure S2, amount of $\mathrm{NO}_{3}{ }^{-}$ stored on watershed surfaces. This material is available free of charge via the Internet at http://pubs.acs.org.

\section{AUTHOR INFORMATION}

\section{Corresponding Author}

*E-mail: rebecca.l.hale@utah.edu.

\section{Notes}

The authors declare no competing financial interest. 


\section{ACKNOWLEDGMENTS}

We thank the Cities of Tempe and Scottsdale for permission and assistance in stormwater sampling. Many thanks to the residents who allowed us to sample their yards. This material is based upon work supported by the National Science Foundation under Grant No. 0504248 and 1063362, IGERT in Urban Ecology, Grant No. BCS-1026865, Central ArizonaPhoenix LTER, and Grant No. 1063362, Impacts of urbanization on nitrogen biogeochemistry in xeric ecosystems (SNAZ). Land cover classifications, based on National Agricultural Imagery Program images, were provided by the Environmental Remote Sensing and Geoinformation Lab at ASU. Kate Lindekugel, Cathy Kochert, David Huber, Sarah Moratto, Nicholas Weller, and others provided valuable field and lab assistance. Three anonymous reviewers provided useful comments on the manuscript.

\section{REFERENCES}

(1) Paul, M. J.; Meyer, J. L. Streams in the urban landscape. Annu. Rev. Ecol. Syst. 2001, 32, 333-365.

(2) Groffman, P. M.; Law, N. L.; Belt, K. T.; Band, L. E.; Fisher, G. T. Nitrogen fluxes and retention in urban watershed ecosystems. Ecosystems 2004, 7, 393-403.

(3) Walsh, C. J.; Roy, A. H.; Feminella, J. W.; Cottingham, P. D.; Groffman, P. M.; Morgan, R. P. The urban stream syndrome: Current knowledge and the search for a cure. J. North Am. Benthol. Soc. 2005, 24, 706-723.

(4) Kaushal, S. S.; Groffman, P. M.; Band, L. E.; Elliott, E. M.; Shields, C. A.; Kendall, C. Tracking nonpoint source nitrogen pollution in human-impacted watersheds. Environ. Sci. Technol. 2011, $45,8225-8232$.

(5) Baker, L.; Hope, D.; Xu, Y.; Edmonds, J.; Lauver, L. Nitrogen balance for the central Arizona-Phoenix (CAP) ecosystem. Ecosystems 2001, 4, 582-602.

(6) Wollheim, W. M.; Pellerin, B. A.; Vorosmarty, C. J.; Hopkinson, C. S. N retention in urbanizing headwater catchments. Ecosystems 2005, 8, 871-884.

(7) Kaushal, S.; Groffman, P.; Band, L.; Shields, C.; Morgan, R.; Palmer, M.; Belt, K.; Swan, C.; Findlay, S.; Fisher, G. Interaction between urbanization and climate variability amplifies watershed nitrate export in Maryland. Environ. Sci. Technol. 2008, 42, 5872-5878.

(8) McClain, M. E.; Boyer, E. W.; Dent, C. L.; Gergel, S. E.; Grimm, N. B.; Groffman, P. M.; Hart, S. C.; Harvey, J. W.; Johnston, C. A.; Mayorga, E.; et al. Biogeochemical hot spots and hot moments at the interface of terrestrial and aquatic ecosystems. Ecosystems 2003, 6, 301-312.

(9) Raciti, S. M.; Groffman, P. M.; Fahey, T. J. Nitrogen retention in urban lawns and forests. Ecol. Appl. 2008, 18, 1615-1626.

(10) Raciti, S. M.; Burgin, A. J.; Groffman, P. M.; Lewis, D. N.; Fahey, T. J. Denitrification in suburban lawn soils. J. Environ. Qual. 2011, 40, 1932-1940.

(11) Hall, S.; Ahmed, B.; Ortiz, P.; Davies, R.; Sponseller, R.; Grimm, $\mathrm{N}$. Urbanization alters soil microbial functioning in the Sonoran Desert. Ecosystems 2009, 12, 654-671.

(12) Groffman, P. M.; Crawford, M. K. Denitrification potential in urban riparian zones. J. Environ. Qual. 2003, 32, 1144-1149.

(13) Zhu, W. X.; Dillard, N. D.; Grimm, N. B. Urban nitrogen biogeochemistry: Status and processes in green retention basins. Biogeochemistry 2004, 71, 177-196.

(14) Grimm, N. B.; Sheibley, R. W.; Crenshaw, C. L.; Dahm, C. N.; Roach, W. J.; Zeglin, L. H. N retention and transformation in urban streams. J. North Am. Benthol. Soc. 2005, 24, 626-642.

(15) Roach, W. J.; Grimm, N. B. Denitrification mitigates N flux through the stream-floodplain complex of a desert city. Ecol. Appl. 2011, 21, 2618-2636.

(16) Larson, E. K.; Grimm, N. B. Small-scale and extensive hydrogeomorphic modification and water redistribution in a desert city and implications for regional nitrogen removal. Urban Ecosyst. 2012, 15, 71-85.

(17) Bettez, N. D.; Groffman, P. M. Denitrification Potential in Stormwater Control Structures and Natural Riparian Zones in an Urban Landscape. Environ. Sci. Technol. 2012, 46, 10909-10917.

(18) Gallo, E. L.; Lohse, K. A.; Brooks, P. D.; McIntosh, J. C.; Meixner, T.; McLain, J. E. T. Quantifying the effects of stream channels on storm water quality in a semi-arid urban environment. $J$. Hydrol. 2012, 470, 98-110.

(19) Gallo, E. L.; Lohse, K. A.; Ferlin, C. M.; Meixner, T.; Brooks, P. D. Physical and biological controls on trace gas fluxes in semi-arid urban ephemeral waterways. Biogeochemistry 2013, DOI: 10.1007/ s10533-013-9927-0.

(20) Silva, S. R.; Ging, P. B.; Lee, R. W.; Ebbert, J. C.; Tesoriero, A. J.; Inkpen, E. L. Forensic applications of nitrogen and oxygen isotopes in tracing nitrate sources in urban environments. Environ. Forensics 2002, 3, 125-130.

(21) Chen, F.; Jia, G.; Chen, J. Nitrate sources and watershed denitrification inferred from nitrate dual isotopes in the Beijiang River, South China. Biogeochemistry 2009, 94, 163-174.

(22) Grimm, N. B.; Foster, D.; Groffman, P.; Grove, J. M.; Hopkinson, C. S.; Nadelhoffer, K. J.; Pataki, D. E.; Peters, D. P. The changing landscape: ecosystem responses to urbanization and pollution across climatic and societal gradients. Front. Ecol. Environ. 2008, 6, 264-272.

(23) Kaushal, S.; Belt, K. The urban watershed continuum: Evolving spatial and temporal dimensions. Urban Ecosyst. 2012, 15, 409-435.

(24) Gallo, E. L.; Brooks, P. D.; Lohse, K. A.; McLain, J. E. T. Land cover controls on summer discharge and runoff solution chemistry of semi-arid urban catchments. J. Hydrol. 2013, 485, 37-53.

(25) Gallo, E. L.; Brooks, P. D.; Lohse, K. A.; McLain, J. E. T. Temporal patterns and controls on runoff magnitude and solution chemistry of urban catchments in the semiarid southwestern United States. Hydrol. Process. 2013, 27, 995-1010.

(26) Hale, R.; Turnbull, L.; Earl, S.; Childers, D.; Grimm, N. Stormwater infrastructure controls stormwater runoff and material expert from arid urban watersheds. Ecosystems Submitted.

(27) Green, P. A.; Vörösmarty, C. J.; Meybeck, M.; Galloway, J. N.; Peterson, B. J.; Boyer, E. W. Pre-industrial and contemporary fluxes of nitrogen through rivers: A global assessment based on typology. Biogeochemistry 2004, 68, 71-105.

(28) Burt, T. P.; Pinay, G. Linking hydrology and biogeochemistry in complex landscapes. Prog. Phys. Geogr. 2005, 29, 297-316.

(29) Lohse, K.; Brooks, P.; McIntosh, J.; Meixner, T.; Huxman, T. Interactions between biogeochemistry and hydrologic systems. Annu. Rev. Environ. Resour. 2009, 34, 65-96.

(30) Powers, S. M.; Johnson, R. A.; Stanley, E. H. Nutrient retention and the problem of hydrologic disconnection in streams and wetlands. Ecosystems 2012, 15, 435-449.

(31) Welter, J. R.; Fisher, S. G.; Grimm, N. B. Nitrogen transport and retention in an arid land watershed: Influence of storm characteristics on terrestrial-aquatic linkages. Biogeochemistry 2005, 76, 421-440.

(32) Larson, E. K.; Grimm, N. B.; Gober, P.; Redman, C. L. The paradoxical ecology and management of water in the Phoenix, USA, metropolitan area. Ecohydrol. Hydrobiol. 2005, 5, 287-296.

(33) Keys, E.; Wentz, E. A.; Redman, C. L. The spatial structure of land use from 1970-2000 in the Phoenix, Arizona, Metropolitan Area. Prof. Geogr. 2007, 59, 131-147.

(34) Roach, W. J.; Heffernan, J. B.; Grimm, N. B.; Arrowsmith, J. R.; Eisinger; Rychener, T. Unintended consequences of urbanization for aquatic ecosystems: A case study from the Arizona Desert. Bioscience 2008, 58, 715-727.

(35) Larson, E. K.; Grimm, N. B. Small-scale and extensive hydrogeomorphic modification and water redistribution in a desert city and implications for regional nitrogen removal. Urban Ecosyst. 2012, 15, 71-85.

(36) Sigman, D. M.; Casciotti, K. L.; Andreani, M.; Barford, C.; Galanter, M.; Böhlke, J. K. A bacterial method for the nitrogen isotopic 
analysis of nitrate in seawater and freshwater. Anal. Chem. 2001, 73, $4145-4153$.

(37) Casciotti, K. L.; Sigman, D. M.; Hastings, M. G.; Böhlke, J. K.; Hilkert, A. Measurement of the oxygen isotopic composition of nitrate in seawater and freshwater using the denitrifier method. Anal. Chem. 2002, 74, 4905-4912.

(38) Kaiser, J.; Hastings, M. G.; Houlton, B. Z.; Röckmann, T.; Sigman, D. M. Triple oxygen isotope analysis of nitrate using the denitrifier method and thermal decomposition of $\mathrm{N}_{2} \mathrm{O}$. Anal. Chem. 2007, 79, 599-607.

(39) Michalski, G.; Scott, Z.; Kabiling, M.; Thiemens, M. H. First measurements and modeling of $\Delta 17 \mathrm{O}$ in atmospheric nitrate. Geophys. Res. Lett. 2003, 30, 4.

(40) Michalski, G.; Meixner, T.; Fenn, M.; Hernandez, L.; Sirulnik, A.; Allen, E.; Thiemens, M. Tracing atmospheric nitrate deposition in a complex semiarid ecosystem using $\Delta 17 \mathrm{O}$. Environ. Sci. Technol. 2004, 38, 2175-2181.

(41) Dejwakh, N. R.; Meixner, T.; Michalski, G.; McIntosh, J. Using O-17 to investigate nitrate sources and sinks in a semi-arid groundwater system. Environ. Sci. Technol. 2012, 46, 745-751.

(42) Kendall, C.; Elliott, E. M.; Wankel, S. D. Tracing anthropogenic inputs of nitrogen to ecosystems. In Stable Isotopes in Ecology and Environmental Science; Blackwell Publishing: Hoboken, NJ, 2007; pp $375-449$.

(43) Lewis, D.; Grimm, N. Hierarchical regulation of nitrogen export from urban catchments: Interactions of storms and landscapes. Ecol. Appl. 2007, 17, 2347-2364.

(44) Anisfeld, S. C.; Barnes, R. T.; Altabet, M. A.; Wu, T. Isotopic apportionment of atmospheric and sewage nitrogen sources in two connecticut rivers. Environ. Sci. Technol. 2007, 41, 6363-6369.

(45) Fenn, M.; Haeuber, R.; Tonnesen, G.; Baron, J.; GrossmanClarke, S.; Hope, D.; Jaffe, D.; Copeland, S.; Geiser, L.; Rueth, H.; et al. Nitrogen emissions, deposition, and monitoring in the western United States. Bioscience 2003, 53, 391-403.

(46) Lohse, K.; Hope, D.; Sponseller, R.; Allen, J.; Grimm, N. Atmospheric deposition of carbon and nutrients across an and metropolitan area. Sci. Total Environ. 2008, 402, 95-105.

(47) Ging, P. B.; Lee, R. W.; Silva, S. R. Water chemistry of Shoal Creek and Waller Creek, Austin, Texas, and potential sources of nitrate; WRI - 96-4167; United States Geological Survey: Reston VA1996.

(48) Buda, A. R.; DeWalle, D. R. Dynamics of stream nitrate sources and flow pathways during stormflows on urban, forest and agricultural watersheds in central Pennsylvania, USA. Hydrol. Process. 2009, 23, 3292-3305.

(49) Burns, D. A.; Kendall, C. Analysis of delta(15)N and delta(18)O to differentiate $\mathrm{NO}(3)(-)$ sources in runoff at two watersheds in the Catskill Mountains of New York. Water Resour. Res. 2002, 38.

(50) Burns, D. A.; Boyer, E. W.; Elliott, E. M.; Kendall, C. Sources and transformations of nitrate from streams draining varying land uses: Evidence from dual isotope analysis. J. Environ. Qual. 2009, 38, 11491159.

(51) Curtis, C. J.; Evans, C. D.; Goodale, C. L.; Heaton, T. H. E. What have stable isotope studies revealed about the nature and mechanisms of $\mathrm{N}$ saturation and nitrate leaching from semi-natural catchments? Ecosystems 2011, 14, 1021-1037.

(52) Chang, C. C. .; Kendall, C.; Silva, S. R.; Battaglin, W. A.; Campbell, D. H. Nitrate stable isotopes: Tools for determining nitrate sources among different land uses in the Mississippi River Basin. Can. J. Fish. Aquat. Sci. 2002, 59, 1874-1885.

(53) Mayer, B.; Boyer, E. W.; Goodale, C.; Jaworski, N. A.; Van Breemen, N.; Howarth, R. W.; Seitzinger, S.; Billen, G.; Lajtha, L. J.; Nosal, M.; et al. Sources of nitrate in rivers draining sixteen watersheds in the northeastern US: Isotopic constraints. Biogeochemistry 2002, 57, 171-197.

(54) Panno, S. V.; Hackley, K. C.; Kelly, W. R.; Hwang, H. H. Isotopic evidence of nitrate sources and denitrification in the Mississippi River, Illinois. J. Environ. Qual. 2006, 35, 495-504.
(55) Vannote, R. L.; Minshall, G. W.; Cummins, K. W.; Sedell, J. R.; Cushing, C. E. River continuum concept. Can. J. Fish. Aquat. Sci. 1980, $37,130-137$.

(56) Thorp, J. H. Metamorphosis in river ecology: from reaches to macrosystems. Freshwater Biol. 2014, 59, 200-210. 